\title{
FINANCING PUBLIC BROADCASTING
}

\author{
HyMan H. Goldin*
}

INTRODUCTION

When the Public Broadcasting Act ${ }^{1}$ passed in November I967 there was joy in the land-at least among the aficionados. The jubilation was understandable: The legislation followed by only eleven months the report of the Carnegie Commission on Educational Television ${ }^{2}$-an impressive Congressional lap-time. Circumstances were most favorable: The concept of educational broadcasting was widely supported; the Johnson Administration and key Congressional leaders of both parties were ardent backers; the highly prestigious Carnegie Commission was unanimous and persuasive; and commercial broadcasters were supportive, as shown by a CBS gift of \$I million to the Corporation for Public Broadcasting.

However, there was one flaw. The Administration, while embracing almost all of the Carnegie Commission's recommendations, sidestepped the most perplexing issue, long-term financing. It urged Congress to establish the new structure and provide seed money from general appropriations, promising to return within the year with proposals for subsequent funding. ${ }^{3}$ The strategy appealed to everyone, for it permitted immediate and very substantial progress. Congress approved and wrote into the Public Broadcasting Act the basic principle that a greatly expanded public broadcasting system was needed in the public interest. It also authorized the establishment of a nonprofit, nongovernmental Corporation for Public Broadcasting to stimulate and foster educational broadcasting. Additionally, the Congressional Committees on Commerce recognized the inevitable need for large-scale federal funding, although not agreeing on the required level of support or the specific techniques for raising the money.

In the interim the Administration changed, and the climate for new tax measures chilled. To win support for new expenditures within the traditional framework of general appropriations is sufficiently difficult. Far harder to realize is public broadcasting's objective of obtaining substantial annual federal funding without resort to the customary appropriations procedures. While accomplishing this goal has become more difficult, it remains, in view of the alternatives, an imperative.

- Associate Professor of Communications, Boston University. Formerly Assistant Chief, Broadcast Bureau, and Chief, Research and Education Division, Federal Communications Commission; Exccutive Secretary, Carnegie Commission on Educational Television.

${ }^{1} 47$ U.S.C. $\$ 390$ et seq. (Supp. IV 1969), amending Educational Television Broadcasting Facilities Act, 47 U.S.C. $\$ 390$ et seq. $(1964)$.

${ }^{2}$ Carnegie Commission on Educational Television, Public Televiston: A Program for Action (rg67) [hereinafter cited as Public Television].

${ }^{3}$ President Lyndon B. Johnson, Message on Education and Health in America, Feb. 28, 1967, in Documents of American Broadcasting 582-84 (F. J. Kahn ed. 1968). 
In discussing the future of educational broadcasting, this paper will discuss the over-all funding problem in terms of estimated dollar requirements, the rationale for federal funding and for avoiding annual budgeted appropriations, and alternative techniques of financing.

Need for Large Scale Funding

The central shortcoming of educational broadcasting is its abject poverty. Deficiencies dog the entire system. Ill-equipped and ill-staffed, educational stations wage a daily struggle for survival.

Educational television (ETV) stations number $\mathrm{r} 82$, one-fourth as many as their commercial counterparts; less than a dozen of the ETV stations have the facilities, staff, and resources to undertake any substantial production of more than local interest. Educational radio stations total four hundred, six per cent of the number of commercial radio outlets; and half of these educational radio stations are lowpowered ten-watt operations.

Educational television transmission is underpowered and in monochrome while competing commercial telecasters are at maximum height and power as well as in color. Educational stations lack sufficient studios, cameras, film chains, videotape recorders, and mobile equipment. Staffs are minimal in size, and few staff producers have the time to plan, research, rehearse, and innovate. Program production beyond static studio formats requires producers, writers, actors, equipment, and funds beyond the resources of the overwhelming majority of these stations. Essential in the operation of a modern, quality television service are technical and program experimentation, audience research, program and station promotion, and the development of creative and managerial talent. For most of educational broadcasting these needs are the stuff of unrealized dreams. The principal evening program source is National Educational Television; absent NET, most educational stations would have little or no public appeal during evenings and weekends.

A comparison with the resources of commercial broadcasting is illuminating and depressing. The entire educational broadcasting service survives on less than three per cent of commercial broadcasting's expenditures. Procter \& Gamble alone spends more than twice as much on its TV budget as the annual support for all the ETV stations. One episode of Bonanza costs more to produce and distribute than the operating expenditures of a typical ETV station over an entire year.

Money is not the only deficiency. To develop into a powerful communications service, public broadcasting will require time, freedom, boldness, creative talent, public involvement, and other ingredients. But without money the potential that exists within public broadcasting to develop these elements will be lost, and inevitably it will be second-rate, mediocre, and impotent—or perhaps nonexistent. 


\section{A. Proposed Model}

The Carnegie Commission's report described and priced a model of a public television system. Its major components and estimated costs are summarized in Table I. The model was planned to expand gradually over twelve years, reaching a long-run steady state by 1980 of $\$ 270$ million annually. The target figures given are minimal. They are limited to television and do not include educational radio, which was added in the public broadcasting legislation.

TABLE I

Costs of a Fully Developed Educational Television System IN THE LONG RUN

\begin{tabular}{|c|c|c|c|c|c|}
\hline & \multirow[b]{2}{*}{ Number } & \multirow{2}{*}{$\begin{array}{c}\text { Basic } \\
\text { Capital } \\
\text { Required* }\end{array}$} & \multicolumn{3}{|c|}{ Annual Costs* } \\
\hline & & & Operating & Capital & Total \\
\hline 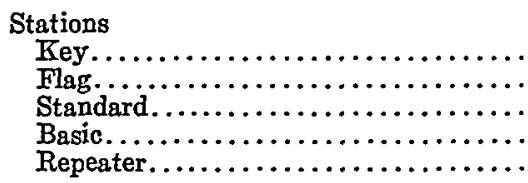 & $\begin{array}{r}20 \\
40 \\
75 \\
75 \\
170\end{array}$ & $\begin{array}{r}124 \\
132 \\
127 \\
95 \\
93\end{array}$ & $\begin{array}{r}60 \\
47 \\
37 \\
12 \\
6\end{array}$ & $\begin{array}{r}12 \\
11 \\
12 \\
10 \\
8\end{array}$ & $\begin{array}{l}72 \\
58 \\
49 \\
22 \\
14\end{array}$ \\
\hline Total. $\ldots \ldots \ldots \ldots \ldots \ldots \ldots \ldots \ldots \ldots$ & 380 & 571 & 162 & 53 & 215 \\
\hline $\begin{array}{l}\text { National Programs } 520 \mathrm{hrs} / \mathrm{yr} \text { (excluding } \\
\text { key station production)......................... }\end{array}$ & & 8 & 23 & - & 23 \\
\hline 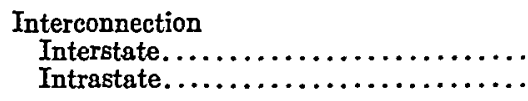 & & $\overline{42}$ & $\begin{array}{l}9 \\
4\end{array}$ & $\overline{4}$ & $\begin{array}{l}9 \\
8\end{array}$ \\
\hline Total..................... & & 42 & 13 & 4 & 17 \\
\hline $\begin{array}{l}\text { Corporation for Public Broadcasting } \\
\text { (nonbroadeast activities)........... }\end{array}$ & & - & 15 & - & 15 \\
\hline Total Costs.... & & 621 & 213 & 57 & 270 \\
\hline
\end{tabular}

* Millions of dollars.

Source: Cafiegre Cougussion on Edecational Television. Public Teletision-A Prograu ron Action 148 (1007).

The estimates are primarily related to public broadcasting, the focus of the Carnegie Report, and do not take account of the financial needs of an expanded in-school, instructional broadcasting service. A commission was appointed under the Public Broadcasting Act to assess the potentialities of new instructional technologies and to project the financial requirements of a nationwide, innovative instructional service.

The Carnegie model has other conservative and restrictive aspects. Color origination equipment was limited to sixty stations, a reasonable compromise for the short run but not for a decade hence when commercial broadcasting will be exclusively, or almost exclusively, in color. Similarly, the projection of national program costs at an hourly average of $\$ 35,000$ is unrealistically low as a longer-term estimate. On 
commercial networks hourly programs are now priced at a minimum of $\$ 170,000$, and the trend of talent costs is rising steeply.

The major value of the Carnegie model is in the direction it points. The resources available to educational broadcasting must take a quantum leap if it is to produce quality programs of interest and substance and compete successfully for public attention. The Carnegie study projected a three-and-a-half-fold growth, which now appears an underestimate of long-term needs. Minor patching and small incremental increases would serve only to leave the present system unchanged. Deprived of a growth potential, public broadcasting would lose its momentum and sink into apathy and formalism. The opportunity it holds of turning television to the best uses of American society would be lost.

\section{B. Current Funds}

A comprehensive record is lacking of total expenditures on the many facets of educational broadcasting, including educational radio, closed-circuit, $2500 \mathrm{MHz}$, programs distributed on commercial television, and research. However, reasonably good estimates are available on the annual total expenditures of NET and the ETV stations and the sources of their funds.

In fiscal I967, IIg stations spent $\$ 62$ million and NET $\$ 9$ million. ${ }^{4}$ Adjusting for overlapping accounts of almost $\$ 3$ million, the net amounted to $\$ 68$ million. ${ }^{5}$

NET's funds came largely from the Ford Foundation. Since the first operation of NET in 1954, the Foundation has been its prime supporter. Other funds are derived from station affliation fees, sales of NET library programs, and underwriting by business firms, but essentially NET's existence has hinged on the largesse of the Ford Foundation.

Contrary to popular belief, the main support of educational stations is government. State and local governments and state universities accounted for half of station funds in $196 \%$, and the federal government contributed another ten per cent. General public and business support is disappointingly low. Public subscribers account for only eight per cent of the total, $\$ 4.5$ million annually, while business and other organizations yield only seven per cent, or $\$ 3.8$ million. Included in the latter figure is underwriting support, for which a business firm receives over-the-air, institutional credit. Foundations, principally the Ford Foundation, gave as much as the public and business firms combined.

\footnotetext{
' See National Assoctation of Educational Broadcasters, Financial and Operating Reports, JurY 1966-JUNE 1967. In fiscal I969, NET's budget rose to $\$ 25$ million as a result of the inclusion of the Public Broadcasting Laboratory and the Children's Television Workshop, both financed in large part by the Ford Foundation and other foundations.

EIn addition to the programs NET acquires from independent producers and from BBC and other foreign and domestic sources, it contracts with public broadcasting stations for the production of programs. The bulk of the station production released on NET is from eight major-market stations: WGBH, Boston; WTTW, Chicago; KCET, Los Angeles; WDNT, New York; WHYY, Philadelphia; WQED, Pittsburgh; WETA, Washington; and KQED, San Francisco.
} 
These signs are not encouraging. Because television is available free, public support is difficult to arouse. Business support, mainly from commercial broadcasters, is spotty. Underwriting is limited basically by the small audiences of individual ETV programs; for the bulk of television advertisers ETV announcements are uneconomic as an advertising investment.

Of major concern is the decline between 1966 and 1967 in state funds, which fell from $\$ 16$ million to $\$ 9$ million. Beleaguered as they are by welfare, education, and urban crises in a period of mounting tax resistance, state and local governments are not likely to increase this support very soon. In time, also, the Ford Foundation will decrease its support and move on to other fields where its seed money can be innovative.

The evidence is overwhelming that the only realistic hope for public broadcasting is tapping the federal tax power. Of course all other sources of support must still be cultivated diligently. They are important both for financial and psychological reasons, for they add a degree of freedom to public broadcasting. But without the massive infusion of additional funds from federal sources, there will be no bright new world for public broadcasting.

\section{II}

\section{Need for Earmarked Tax and Spectal Trust Fund}

Granted the unfortunate necessity of relying primarily on federal funding, what mechanisms can insulate public broadcasting from the dangers and abuses of close governmental oversight and political control? If the objectives are to foster a free and critical broadcast press, and to maximize innovations and creativity, direct governmental involvement must be minimized. Yet the very visibility of the service, its ubiquity, and its hoped-for currency and impact in political and social disputes make it an inevitable target.

\section{A. Policy Dilemma}

This dilemma evades ideal solutions. At issue are primary democratic values: on the one hand, a truly free press and, on the other, Congressional responsibility for the expenditure of federal funds. The Carnegie Commission's recommendation was an existential compromise. It urged that half of the federal funds be appropriated through the regular procedures and that half flow from an earmarked tax into a trust fund.

The Carnegie Commission classified the financial needs of public television into three categories: plant, operating expenses, and "outside" programming. Federal funds for the first and second types of expenses were to be provided through the Department of Health, Education, and Welfare. The long-term annual federal share for these activities was estimated at $\$ 90$ million, and these monies would be subject to the normal appropriation procedures, including Budget Bureau and Con- 
gressional oversight. The Carnegie Commission's implicit hope was that these expenditures would be voted annually without undue governmental involvement in the specific content of public television's broadcasts.

On the other hand, the \$roo million the Corporation for Public Broadcasting would spend annually on programming and allied activities was to be raised and disbursed outside of the budgetary and appropriation process. It was to come from a manufacturers' tax on television sets, beginning with a two per cent levy to raise $\$ 40$ million, and rising ultimately to five per cent to yield $\$$ roo million. The tax would be collected by the Treasury Department and credited to the Corporation, which would spend the funds for support of programs, station interconnection, personnel training, research, and development.

In support of its proposal the Carnegie Commission contended that the Corporation and the trust fund were "jointly essential to the insulation of Public Television from the dangers of political control. At the same time, Congress retains the power to terminate the arrangement at any time; its ultimate control over the expenditure of public funds is not impaired."

\section{B. Precedents}

There is a long tradition of aiding nongovernmental organizations with public funds. Examples include the National Academy of Sciences, Howard University, and the Smithsonian Institution. Similarly, there are well-established precedents for earmarking of public funds, including tax revenues, for specified purposes. Familiar illustrations are the Highway Fund, the Old Age and Survivors Insurance Trust Fund, the Disability Insurance Trust Fund, the Railroad Retirement Account, the Migratory Bird Conservation Fund, and the Wildlife Restoration Fund.

The innovative element in the Carnegie proposal was the decision to wed the two features. There is no precise precedent for earmarking tax revenues for disbursement to a private entity. Nevertheless, the Commission's legal counsel concluded that nothing in the combination of the two features "diminishes the force of the precedent behind each of them separately so as to render the result improper."

The Commission's compromise may be objected to as naive. It would be unrealistic to ignore the fact that, if it wished, Congress could find many ways of constraining educational broadcasting. It already has one potentially chilling lever-namely that educational stations, like their commercial counterparts, are licensed by a federal agency. In addition, under the Carnegie Commission's proposal, Congress would deal annually with requested appropriations for public broadcasting facilities. Even if Congress were to authorize a trust fund for educational broadcasting, it could modify or repeal the earmarked tax at any time.

Yet acceptance by Congress of a special tax and a trust fund is not to be

\footnotetext{
${ }^{\circ}$ Public Telenvion, sipra note 2 , at 69 .

${ }^{7} I d$. at 126 .
} 
dismissed as a symbolic exercise. As in many policy areas the issue is not "either-or" but "more or less." In debating the issue, Congress would create legislative history to buttress further the independent role of educational broadcasting. Some precedents already exist: a section of the Educational Television Facilities Act of 1962 prohibited federal interference or control by any department, agency, officer, or employee of the United States "over educational television broadcasting or over the curriculum, program of instruction, or personnel of any educational institution, school system, or educational broadcasting station or system." This section is retained in the Public Broadcasting Act of 1967 . In addition, the latter act authorizes the Corporation for Public Broadcasting to "carry out its purposes and functions and engage in its activities in ways that will most effectively assure the maximum freedom of the noncommercial educational television or radio broadcast systems and local stations from interference with or control of program content or other activities." Undoubtedly, passage of an earmarked tax and trust fund would include language that could be cited to fend off gross attempts to control the program content of educational broadcasting.

This special funding arrangement would have other benefits. It would increase the probability of stable year-to-year funds, relatively unaffected by changes in fiscal policy, shifts in Administration, or the various other forces that inevitably influence the government's budget. A change in the earmarked tax would be unusual and would evoke public attention. If public broadcasting can realize more of its potential and develop broader public support, funding need not be manipulated to squelch critical or unpopular programming. Most important, the earmarked tax would permit an orderly expansion and the long-term development of public broadcasting.

\section{Governmental Influences}

While the discussion has focused thus far on insulation from Congressional influence, dangers of intervention lurk in other governmental sources. The Carnegie Commission recommended that the Corporation for Public Broadcasting be governed by twelve trustees, six to be chosen by the President with the consent of the Senate; these trustees in turn were to select the other six. The Johnson Administration, in presenting its bill, ignored this recommendation and proposed a fifteenman board, all to be selected by the President with the consent of the Senate.

Concern was expressed during the legislative consideration of the bill that public broadcasting could be captured by the Administration in power and become its political press, and various safeguards against this eventuality were inserted in the legislation. No more than eight trustees of the Corporation for Public Broadcasting may be from the same political party, and no educational station may editorialize or support or oppose a political candidate.

\footnotetext{
${ }_{47}^{8}$ U.S.C. $\$ 397(1964)$.

${ }^{\circ} 47$ U.S.C. $\$ 396(\mathrm{~g})$ (I)(D) (Supp. IV rg6g).
} 
Another concern is the role of the Department of Health, Education, and Welfare. In its administration of the Educational Television Broadcasting Facilities Act since $I 962$ it has been exemplary in not interfering with the programming freedom of educational broadcasting. However, in earlier years the funds available for financing the physical expansion of stations were equal to or greater than the demand. Currently the funds available to HEW for facilities grants are a fraction of the demand, and the agency must make difficult allocation choices.

In this context, it is significant that in the fashioning of the public broadcasting bill, HEW vetoed the Carnegie Commission's recommendation that the Department should disburse operating funds as well as monies for physical plant. The Department, sensitive to the nexus of operating and program funds, insisted that both should be the Corporation's responsibility.

HEW's objections were well taken. Operating funds finance staff producers, directors, cameramen, and other staff program personnel, and, therefore, are more appropriately the Corporation's responsibility. In this respect the public broadcasting legislation improved on the Carnegie Commission's recommendation.

\section{Federal Financing Since 1967}

The experience with federal appropriations for ETV since 1967 is instructive. Even if ill will is absent, public broadcasting holds a low priority in the competitive struggle for scarce funds. In 1968, for example, the act authorized \$12.5 million for Title I (facilities) and $\$ 9$ million for Title II (the Corporation). These minimal sums were subsequently cut by the appropriations committees to $\$ 4$ million for HEW and $\$ 5$ million for the Corporation.

For fiscal I970, the outgoing administration recommended $\$ 5$ million for facilities and $\$ 20$ million for the Corporation. The Nixon Administration, in presenting its revised budget to Congress, slashed the funds for the Corporation by half. However, legislative authorization for these funds was required, and the request came before the Senate Commerce Committee, a strong supporter of public broadcasting. In public hearings on the authorization, Senator Magnuson, chairman of the committee, commented wryly that the Defense Department "spills that much in a week," and Senator Hartke contrasted the miniscule request for public broadcasting with the war in Vietnam which is costing about a million dollars every 15 minutes or $\$ 96$ million a day. ${ }^{10}$

The Senate and the House voted to restore the $\$ 20$ million authorization for the Corporation, but before this sum is actually disbursed approval is required from both appropriations committees. The strong likelihood is that a lesser sum will be voted finally.

Without minimizing the political and policy difficulties that need to be resolved, public broadcasting urgently needs an earmarked tax and trust fund. It is clear

\footnotetext{
${ }^{10}$ Brosdcasting, May 5, 1969, at 54 .
} 
that, at least in the short run, annual appropriations will not generate the level of financial assistance that is required, and that both symbolically and practically an insulated trust fund adds to the potential freedom of public broadcasting. Although free of advertiser pressure, educational broadcasting is encircled with other restraints and controls-conservative boards of trustees, financial support from "establishment" elements in the community, and tax support from state legislatures and local school boards. Innovation and daring will entail risks and conflict irrespective of the nature of federal financing. Public broadcasting needs every degree of openness, every layer of insulation, every assurance of stable and substantial financial support, every encouragement to experiment. That it can be "freer" with an earmarked tax than with annual appropriations is certain. That it has a better opportunity to expand into a modern high-quality broadcast service with an earmarked tax and funds of sufficient magnitude is indisputable.

\section{E. Opposition}

Equally clear, however, is the opposition by the Treasury Department to earmarked funding. In the context of national fiscal policy, special tax funds are to be avoided as the plague. They diminish the scope of executive and legislative functioning and reduce the opportunities for flexibility in fiscal policy.

The opposition in principle is substantial and cannot be dismissed cavalierly. Clearly, earmarked funds should be avoided if a practicable alternative is available. In the present instance a workable alternative is lacking. Annual appropriations would defeat the objective of establishing and nurturing a free, independent, and expansive communication service. Moreover, in the context of a federal budget of $\$ 200$ billion, the specific sums required for a public broadcasting fund are of very minor fiscal significance.

\section{III}

\section{Funding Aiternattves}

Assuming acceptance of a special fund, the list of new federal taxes, or tax-like revenue devices, proposed as possible sources of funds for public broadcasting includes the following:

(I) A tax on gross receipts of radio and television broadcasters.

(2) A tax on the gross receipts of all FCC interstate licensees, including longdistance telephone and domestic and overseas telegraph, as well as broadcasters.

(3) A tax on total television advertising outlay.

(4) A tax on the net profits of broadcasters.

(5) An excess profits tax on broadcasters.

(6) A charge for lease of or access to the radio spectrum.

(7) An annual home license fee.

(8) A manufacturers' excise tax on radio and TV sets. 
Other possibilities have been suggested that are not tax measures but do require governmental authority. These would, however, yield only limited and supplementary sums. They include (I) a nonprofit domestic satellite service for commercial and educational broadcasting; (2) a national system of subscription public television; and (3) limited advertising on public broadcasting.

Three studies have assessed the tax alternatives on various grounds including economics, equity, and administrative feasibility. The studies concluded with somewhat differing preferences. All agreed, however, on the essential need for an earmarked tax and a trust fund.

The Carnegie choice was an excise tax on TV receivers. ${ }^{11}$ Dr. Joseph A. Pechman, Director of Economic Studies at the Brookings Institution and consultant to the Ford Foundation, preferred a tax on long-distance communications, with a tax on broadcasting revenues or a manufacturers' excise tax on radio and TV sets as close alternatives. ${ }^{12}$ The author of the third study, Professor Dick Netzer, chairman of the Department of Economics at New York University and consultant to the National Citizens Committee for Broadcasting, opted for a tax on broadcasting revenues and a spectrum-use charge. ${ }^{13}$

\section{A. Tax on Sets}

The Carnegie model involved three separate sources of support: an excise tax on television receivers; annual appropriations administered by HEW; and the traditional nonfederal sources of funds (state and local government, state universities, private subscribers, business donors, and foundations). Ultimately, a five per cent excise tax, yielding \$roo million, would go to the Corporation for Public Broadcasting for program development, interconnection, and other national objectives. HEW would seek appropriations of \$gr million annually for plant and station operations; and nonfederal sources would contribute $\$ 75$ million for the same purposes. ${ }^{14}$

Two changes in the above model are required. As noted above, the legislation authorized the Corporation rather than HEW to supply operating funds. As a result the target budget for the Corporation should be set at approximately \$155 million rather than \$10o million. In addition, the Carnegie report was limited to television, but the Public Broadcasting Act also included educational radio. As a minimum this raises the Corporation's annual requirements by at least \$ro million. At the same time, inclusion of radio within the Corporation's ambit adds weight to the arguments for taxing radios as well as TV sets.

\footnotetext{
11 Public Television, stipra note 2, at 68-73.

${ }^{2}$ Possible Tax Revenues for Non-Commercial Television, Reply Comments of the Ford Foundation, Establishment of Domestic Noncommon Carrier Communications Facilities by Nongovernmental Entities, No. I6495 (F.C.C., filed Dec. I2, I966).

${ }^{13}$ D. Netzer, Long-Range Financing of Public Broadcasting 20-21 (National Citizens Committee for Broadcasting, 1969).

14 Public Television, stipra note 2, at 75 .
} 
The proposed tax on receivers has merits and shortcomings. As a practical consideration, there is ample precedent for the tax: from I950 to I962, a ten per cent manufacturers' excise tax was levied on radio and television sets. Administration of the tax proved economical and feasible. The number of set manufacturers is relatively small, collection costs are low, and evasion is minimal. ${ }^{15}$

As a second advantage, the linkage with benefits is evident. The tax, originally imposed on manufacturers, would be passed directly on to the general public who stand to benefit from public broadcasting. In the course of a decade practically every household buys a TV set, in addition to several radio sets, and the tax would be borne by the entire population. An expanded public broadcasting service will clearly benefit the public in expanding the variety and quality of program services.

The set market is an adequate, although not ideal, tax base. The industry is undergoing a major product change, with color sets replacing monochrome. Overall, one-third of home sets are color, leaving a current potential of forty million homes to convert to color in the future. Color sets are three or four times as expensive as monochrome. The manufacturer's price for a typical black-and-white set is $\$ 92$, and for a typical color set $\$ 343^{10}$

A second major trend is the increase in multiple sets. At present almost forty per cent of all households have two or more TV receivers. Continued expansion in sets per home will also serve to maintain set sales at a high level during the next decade. While TV may not duplicate the experience of radio, multi-TV-set homes are proliferating.

The prospects are bright that over the next decade or more the factory value of TV-set sales will average over $\$ 2$ billion annually, after allowing for competitive price reductions. The market for radio sets is relatively stable, and on an annual basis manufacturers' value approximates \$o.4 billion.

No tax measure is popular, and a critical step in assessing prospective tax measures is to estimate the forces of political opposition. Set retailers are large in number, highly price conscious (with discounting prevalent in the larger cities), and generally concerned about maintaining profit margins. Raising the price charged the consumer adversely affects the units sold, although the precise magnitude of the reduction is uncertain. However the tax generally can be passed on to consumers.

One demerit of the tax is that it is regressive. The burden is not graduated by income and therefore bears more heavily on lower-income families. This aspect has actively concerned the Treasury Department. While recognizing the social and economic desirability of equitable and progressive taxation, some regression is not always avoidable, and if the burden is minimal it is tolerable. Unlike certain other taxed items, family expenditures on sets are periodic. A television set has

\footnotetext{
${ }^{18}$ Nine firms produce almost $90 \%$ of domestic television sets.

${ }^{10}$ The figures cited in the text are factory prices of domestic-brand sets in 1968. See Telzvision Digest, March 24, 1969, at 9.
} 
a useful life of eight to ten years, and over this period the effect of the tax accretion is slight. At the five per cent tax level, the initial tax would amount to $\$ 5-\$ 16$; $^{17}$ amortized over eight years the annual impact ranges from sixty cents to $\$ 2.00$. At this level regressiveness is not a weighty objection.

The above sums were computed on the basis of manufacturers' value. As a TV set passes through distribution channels to the retailer its ultimate price to the consumer may increase by thirty per cent or more. There is no reason for permitting the tax to the consumer to increase concomitantly. The tax legislation will need to include a requirement for disclosure to the consumer of the initial manufacturers' tax. Recent consumer legislation, including truth-in-lending and price disclosure in automobile sales, are ample precedents. If required to specify to the consumer the initial tax, the set retailer is unlikely to add his normal mark-up to the tax.

Another argument against the set tax is its alleged lack of stability and growth potential. These arguments were levied by Professor Netzer in his study, LongRange Financing of Public Broadcasting. ${ }^{18}$ In Netzer's view these objections are so serious as to make the set tax a much less attractive alternative than a tax on the gross revenues of broadcasters. By comparison, gross broadcasters' revenues are less subject to fluctuation and more likely to grow annually. However, Professor Netzer's arguments against the tax on sets are overstated, at least as they pertain to the next decade. In analyzing the trends of set production it is essential to take account of the change to color. While present color standards were adopted in 1953, it was not until I964 that production and sale of color sets began to take hold. Thus, the cycle since 1964 should be differentiated from set production during $1955-63{ }^{19}$ Table 2 sets forth manufacturers' value of TV sets produced since 1964 , and shows the annual yield with three per cent and five per cent taxes. The variations in yield from a set excise tax are within a tolerable range. The Corporation for Public Broadcasting would not be required to dispose of tax funds on a twelve-month cycle but could carry funds over, and its expenditures could be budgeted over a time period that would tend to minimize yearly variations in yield.

As monochrome production declines and color predominates, aggregate value during the next several years will reach close to $\$ 3$ billion. Even when the market ultimately stabilizes, with demand chiefly for replacement, the annual value should be in the neighborhood of $\$ 2$ billion to $\$ 2.25$ billion. By that time, a major techno-

\footnotetext{
${ }^{17}$ Assuming $\$ 92$ as the average factory price for a black and white set and $\$ 343$ for a color receiver.

${ }^{18}$ Nerzer, stlpra note 13 .

10 Table 3 of the Netzer study, supra note 13, at 26, shows average annual growth rates of alternative taxes for $1963-66$, 1960-66, and $1955-66$. For the first and second periods, the growth in value of TV set production surpasses the alternatives. For the third period (1955-66), the value of TV set production ranks lowest in relative growth. But Netzer failed to recognize the economic significance of the shift to color production. Moreover, in Table 2 (id. at 25), he measures year-to-year stability of alternative taxes for the period I955-66 without taking account of the change to color production after x963.
} 
TABLE 2

Estimated Factory Value of Domestic-Brand TV Sets, 1964-69, and Projected Tax Yields

\begin{tabular}{|c|c|c|c|}
\hline$\cdot$ & $\begin{array}{l}\text { Factory Value } \\
\text { (billions of dollars) }\end{array}$ & \multicolumn{2}{|c|}{$\begin{array}{l}\text { Tax Yield at: } \\
3 \% \quad 5 \% \\
\text { (millions of dollars) }\end{array}$} \\
\hline 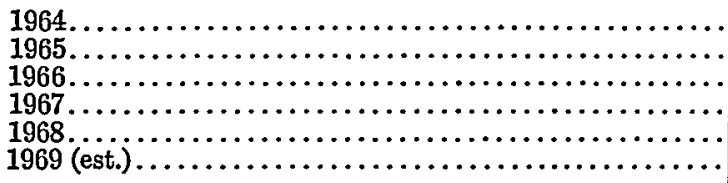 & $\begin{array}{l}1.4 \\
1.8 \\
2.6 \\
2.5 \\
2.6 \\
2.4\end{array}$ & $\begin{array}{l}42 \\
54 \\
78 \\
75 \\
78 \\
72\end{array}$ & $\begin{array}{r}70 \\
90 \\
130 \\
125 \\
130 \\
120\end{array}$ \\
\hline
\end{tabular}

Source: 38 Teueviston FactBoos 58-a (1968); Televiston Digest, March 24, 1969, at 10. Note: The abovo figures aro limited to TV sets only. Addition of radio sets-home and car-would increase annual yield by about $\$ 12$ million $(3 \%$ tax) or $\$ 20$ million (5\% tax). Foreigo imports, a significantly growing sector, are also omitted.

logical innovation is likely. The possibilities include wide-view wall sets, threedimensional receivers, and car television. Also in the offing are sets with revolutionary, cost-economizing components. While it is difficult to predict the longer-run trends in TV set production, there is a good probability that the value of sets will stabilize at a high level for at least the next decade.

\section{B. Tax on Long-Distance Communications}

In the memorandum entitled Possible Tax Revenues for Non-Commercial Television which he prepared for the Ford Foundation, Dr. Pechman assumed that total financial requirements would be on the order of $\$ 200$ million annually. ${ }^{20}$ He expected that half of this amount might be raised from nonfederal sources and from a special nonprofit domestic satellite service. He recommended that the other \$roo million be raised by a one per cent tax on all long-distance communications. Less preferred but almost as meritorious were a three per cent tax on broadcasting revenues or a five per cent manufacturers' excise tax on radio and TV sets.

The tax favored by Dr. Pechman would affect the telephone and telegraph industries as well as the radio and TV industries. The estimated revenues of these industries aggregate about $\$$ ro billion, and this tax base is marked both by stability and growth.

Dr. Pechman assumed that the communications tax would be shifted to the general public. He argued that it would be paid by all or most of the nation's citizens either directly, as users of toll telephone and telegraph, or indirectly, through higher product prices charged by firms using long-distance communications and broadcasting advertising. Since the public would benefit from the improvement in noncommercial broadcasting, he defended the tax as benefit-linked. Dr. Pechman did not present any evidence to support his generalization. It is somewhat less likely that the tax would be passed on to consumers than the set excise tax.

\footnotetext{
${ }^{20} I d$. at 35 . This estimate preceded the detailed cost estimates prepared by Arthur D. Little for the Carnegie Commission.
} 
A large number of business firms, operating in a variety of market conditions, use toll telephone, and it is likely that a significant proportion of the tax would have to be absorbed. The lack of benefit-linkage for these firms would argue against adoption of the tax.

Dr. Pechman assumed that the present ten per cent tax on toll telephone use would be lowered to one per cent on April I, Ig68, and would expire on January I, 1969. Such was the Congressional intent in 1966 , but the exigencies of the Vietnam War and other governmental crises have resulted in continuance of the ten per cent excise tax. Political and equity considerations clearly rule out any present increase in the tax to benefit public broadcasting.

Of subsidiary financial interest in connection with the Ford Foundation's position was its espousal of a social dividend to be derived from establishment of a nonprofit domestic satellite corporation servicing the broadcast networks; the earnings of this corporation would be applied to the support of public broadcasting. The proposal in its entirety has many ramifications. It involves the principle of a private, limited-purpose satellite rather than the multi-purpose, common carrier service advocated by Comsat, AT\&T, and the other interested communications companies. It assumes that satellite interconnection of stations would be more economical than the land-based AT\&T service and that the networks would share the economies with public broadcasting. It also projects highly simplified ground transmitting as well as receiver equipment for connection with the satellite so that individual ETV stations could transmit local events of significance to other stations and to the public broadcasting network. Finally, the Ford proposal also contemplates that the satellite would provide free interconnection for the educational network.

The specific sums potentially available for public broadcasting from the Ford proposal are estimated at $\$ 20$ million to $\$ 30$ million annually. As such they would meet about ten per cent of public broadcasting's projected requirements.

Aside from its merits as a support for public broadcasting, this proposal generates thorny issues of public policy in the satellite field. At best it would serve as a supplementary source of funds, which would be welcome, but in no way is it a solution for the long-term funding needs of public broadcasting.

\section{Tax on Broadcasting}

The objective of this proposal developed by Professor Netzer, and espoused by the National Citizens Committee for Broadcasting, is to raise \$270 million annually without any resort to direct federal appropriations. While not excluding the role of philanthropy, independent fund raising, or state and local governments, the model does not specifically project support from such sources.

The recommended package of financing proposals includes the following: ${ }^{21}$

${ }^{31}$ Id. at 20. 
(I) a tax on commercial broadcasting's gross receipts, at a rate of perhaps four per cent, yielding over $\$ \mathrm{r} 20$ million annually, to be assigned to the proposed trust fund; and

(2) some system of charging for access to the spectrum, designed to yield at least $\$ 50$ million a year, also to be assigned to the proposed trust fund.

In addition, supplementary financing would be obtained from these nongovernmental sources: ${ }^{22}$

(I) establishment of the Ford Foundation's proposed broadcasters' nonprofit satellite system, with ninety per cent of its net proceeds assigned to the proposed trust fund, yielding $\$ 20$ million a year in money as well as substantial benefits from the value of free interconnection;

(2) authority for public broadcasters to accept advertising, under appropriate limits and controls; and

(3) authority for public broadcasters to experiment with subscription television.

In total, this package is described as capable of providing funds at the recommended $\$ 270$ million annual level. However, Netzer attached the highest priority to creation of the trust fund and adoption of the gross receipts tax on broadcasting.

A tax on broadcast revenues to finance public broadcasting was also supported in the Carnegie Report by Joseph McConnell, president of Reynolds Metals Company and formerly president of NBC. In a concurring opinion to the Report, he stated in part, $^{23}$

I suggest that those who are licensed to use the airways in the "public interest" - the television stations-should at least share in the cost of Public Television. If they should pay a franchise tax for that purpose, we can assume, as in the case of the tax on television sets, that this would be passed along to the purchaserthe advertiser. Perhaps it is the advertiser, with his basic test of program content, to whom we refer . . . when we speak of "acceptability—which ... keeps commercial television from climbing the staircase." If this is what has brought about the need for Public Television, it would seem to me to be equitable that the advertiser bear a part of the cost, so that television could realize the promise for it so ably and so eloquently set forth in the Commission's Report.

In 1966, prior to the issuance of the Carnegie Report, a major broadcaster also tentatively advanced the possibility of a tax on broadcasting, but he sought a quid pro quo for his heretical views. In return for several million dollars per year to be given educational television, commercial broadcasters would be relieved of responsibility to program for minority tastes. Broadcasters in all good conscience could maximize profits, absolved of any guilt for failure to discharge their public service responsibilities. The proposal was incredibly naive and won no support. Not only

\footnotetext{
${ }^{22} I d$. at $2 \mathrm{I}$.

${ }^{28}$ Public Television supra note 2 , at 72 .
} 
were the sums to be made available to educational television trivial, but the underlying notion that Congress, the FCC, the public, or even the industry would formally and openly accept the principle that broadcasting should operate as a purely private enterprise showed a gross misunderstanding of regulatory gamesmanship.

The arguments for a tax on broadcasters' gross receipts are substantial. First, it would tap a large, stable, and expanding revenue source. Total revenues for the broadcast industry are currently estimated at $\$ 3.5$ billion and are expanding at an average rate of seven per cent per year. Since I957 each year's total has exceeded the previous year's. (See Table 3.)

Another argument for the tax is that it would siphon off some of the monopoly profits of an industry affected with the public interest and operating on a public resource. Over-all, commercial broadcasting, particularly VHF television, is highly profitable. The average annual revenues of a VHF station are over $\$ 2$ million, and the ratio of pretax profits to revenues is over twenty-five per cent. ${ }^{24}$ Many TV stations enjoy at least roo per cent returns on investment. Because of the limited number of network systems, the limitations on entry, and the strong comparative advantages of VHF stations, large economic rents are built into the values of these stations. A station in Houston sold for $\$ 4$ million in I955, whereas a comparable station in the same market went for $\$ 20$ million in 1967 .

The pervasiveness of economic rent is indicated by an industry-sponsored study which estimated the economic value of 127 VHF stations in the top fifty markets at $\$ 3$ billion, an average of $\$ 23$ million per station. ${ }^{25}$ Of these estimated values, less than twenty per cent are likely to be accounted for by investments in physical plant or other tangible assets. The underlying factors enabling a station to satisfy advertiser demand and accrue large annual earnings are its license from the FCC, with the concomitant limitations on entry of effective competitors, and its network contract with ABC, CBS, or NBC.

The networks and the larger television and radio stations can easily absorb a five per cent tax on gross receipts yielding over \$roo million. Such a tax would not be unduly burdensome under current and foreseeable conditions. It would doubtless be shifted in part through higher charges to advertisers, who would in turn attempt to recover the tax, in part at least, by shifting it forward in the form of higher prices to consumers. The tax might also be offset in part by lower payments to factor inputs, possibly resulting in some reduction in the extremely high talent payments. Finally, if a new tax is imposed and allowed as a deduction by the Internal Revenue Service, nearly half (forty-eight per cent) of it will be paid, in effect, by the federal Treasury in the form of lower corporate income tax collections.

\footnotetext{
34 These figures are for 5967 and exclude the 15 network-owned stations. The network-owned-andoperated stations had average per station revenues of $\$ 17.7$ million and pretax profits of $\$ 6.9$ million, a profit ratio of almost 40\%. TV Broadcast Financial Data-ig67, FCC Release No. 26097 (Dec. 3I, xg68).

${ }^{26}$ Broadcasting, Feb. 3, 1969, at 19-22.
} 
TABLE 3

Annual Broadcast Revenues, Networks and Stations, Radio and Television, I $957-68$

\begin{tabular}{|c|c|c|c|}
\hline Year & Radio & $\underset{\text { Jllars) }}{\mathrm{TV}}$ & Total \\
\hline 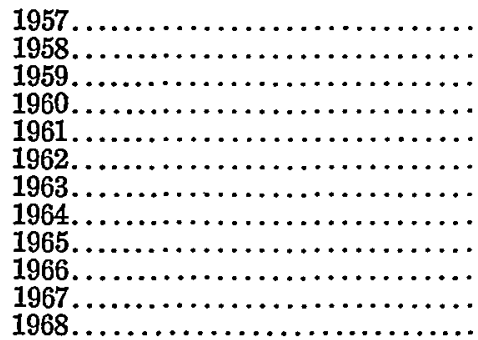 & $\begin{array}{r}515.2 \\
520.6 \\
555.7 \\
591.9 \\
583.6 \\
626.8 \\
669.7 \\
719.2 \\
776.8 \\
852.7 \\
907.3 \\
1,022.9\end{array}$ & $\begin{array}{r}943.2 \\
1,030.0 \\
1,163.9 \\
1,268.6 \\
1,318.3 \\
1,486.2 \\
1,597.2 \\
1,793.3 \\
1,964.8 \\
2,203.0 \\
2,275.4 \\
2,520.9\end{array}$ & $\begin{array}{l}1,458.4 \\
1,550.6 \\
1,719.6 \\
1,860.5 \\
1,901.9 \\
2,113.0 \\
2,266.9 \\
2,512.5 \\
2,741.6 \\
3,055.7 \\
3,182.7 \\
3,543.8\end{array}$ \\
\hline
\end{tabular}

Source: Federal Communications Commission.

A tax on broadcasting can also be justified on the ground that the federal government permits broadcasters to use the public's spectrum virtually free. Taxation of the industry can be regarded as payment for the benefits of frequency use and for control of technical interference so essential for the broadcasting industry.

More recently, the precedents of cable television offer additional arguments for a tax on the gross revenues of broadcasters. In seeking local licenses CATV companies usually agree to turn over to the local government five per cent of their annual gross revenues. In some communities, the cable TV interests share a significantly larger percentage of their revenues with the city. The rationale for a federal tax on the revenues of broadcasters is no less substantial.

On the other side of the ledger are various philosophical and practical considerations. The linkage with benefits, for example, is weaker than for the tax on radio and TV sets. To the extent that audiences or talent were diverted to public broadcasting the disadvantage to the commercial broadcasters is evident. On the other hand, operating commercial broadcasters benefit from the withdrawal of the II5 VHF assignments presently reserved for educational broadcasting. Were the operating VHF educational stations to go dark as a result of the absence of financial support, their channels would eventually be reassigned for commercial use, resulting in increased advertising competition and reduction of the revenues and profits of some of the existing stations.

In any event, it would be undesirable to levy the tax on all broadcasters. While the industry is highly profitable on an aggregative level, a large number of broadcast stations are unprofitable or operate at the margin. This includes some $1,500 \mathrm{AM}$, FM, and TV stations. As public policy is committed to the maintenance and fostering of the largest number of local broadcast units, a gross receipts tax on unprofitable or marginal stations would conflict with these other social objectives. This objec- 
tion can be overcome by limiting the tax to stations with established records of profitability, or with revenues above specified levels. This would reduce the tax base by perhaps twenty-five per cent but is not a dispositive objection.

Another objection is to the inclusion of network operations in the industry total. The networks' share of total operating revenues, exclusive of their owned and operated stations, amounts to forty per cent of the industry total. Networks do not use the frequency spectrum and are therefore not precisely in the same position as stations. However, the nexus of networks and stations is very immediate, and network operation is integral to broadcasting, at least for television. ${ }^{26}$

In the pragmatic, nut-cracking process of drafting legislation, it is altogether conceivable that, absent other objections, Congress could justify the network relationship to broadcasting as unique and require networks to share with stations the burden of supporting public broadcasting. The ultimate obstacle is the political difficulty of passing a special tax on commercial broadcasting. Broadcasters are well organized at the state and national levels and would have many allies in this struggle. Congress and the Administration are highly sensitive to the role of the electronic media as primary intermediaries with constituents, and in the face of highly organized opposition by broadcasters and advertisers, the political roadblocks to such a tax are very substantial.

\section{Spectrum-Use Tax}

Economists examining the structure of broadcasting contend that the present system of frequency allocations is wasteful and inefficient. This they attribute principally to the treatment of the spectrum as a free good. Demand for frequency space is not rationed by price as are other economic goods, and consequently it greatly exceeds supply. Furthermore, there is no mechanism for exchange of frequencies among users: thus a large segment of UHF broadcast space goes undeveloped, although users in other market segments are congested.

Professor Ronald Coase and others have urged the use of the pricing mechanism in allocations for more rational and efficient utilization of a congested spectrum. ${ }^{27}$ Professor Netzer espouses the same view and concludes that it is not unreasonable to assign such revenues to public broadcasting. ${ }^{28}$

Using the price mechanism to allocate the spectrum involves complex technical and political issues with national defense and international ramifications. It is not at all clear, for example, that the market mechanism can cope efficiently with interference and other aspects of spectrum use. At a conference of economists, lawyers, and broadcast specialists on the Use and-Regulation of the Radio Spectrum

${ }^{28}$ See Goldin, The Television Overlords, AtLantrc MonTHLY, July 1969 , at 87-89.

${ }^{27}$ See Coase, The Economics of Broadcasting and Government Policy, 56 AMs. EcoN. Rev. 440 (1966); Jones, Use and Regulation of the Radio Spectrum: Report on a Conference, in Communications and the Future: A Symposizm, I968 WASH. U.L.Q. 7r.

${ }^{28}$ NETZER, supra note 13 , at 19. 
held in 1967 under the auspices of the Brookings Institution and Resources for the Future, the consensus was that it was too late in the history of broadcasting to adopt direct pricing mechanisms, whatever their technical merits. ${ }^{20}$

Aside from the sale of frequency assignments, a substantial license tax could be imposed on spectrum users. A precedent for such action is the federal government's practice of charging for mineral and timber rights on public lands. Beginning in 1964, the FCC has imposed license fees to recover part of the licensing costs. The fees are minimal (\$150 per application for television and $\$ 75$ for radio), and the annual yield is only $\$ 4$ million. However, imposition of even these small charges encountered considerable opposition within the communication industries and Congress. The political feasibility of raising the returns from $\$ 4$ million to $\$ 50$ million, as recommended by Netzer, is slight. Nevertheless, on the merits a strong case can be made that FCC fees should be increased substantially. Higher charges would tend to decrease certain marginal uses of the spectrum. The monies collected should be used to cover the $\$ 22$ million annual costs of FCC operations, or, alternatively, should be designated as a social dividend to assist in the support of public broadcasting.

\section{E. Advertising}

Professor Netzer suggested that public broadcasting be permitted to accept advertising on a controlled basis. He recognized some of the difficulties in this course: the need to prevent interference with program content; the avoidance of obnoxious forms of television advertising; and the high cost-per-thousand of such advertising because of public broadcasting's small audiences. ${ }^{30}$ Nevertheless, Netzer concluded that controlled acceptance of advertising may be a useful supplementary source of funds, especially for individual costly programs. He did not, however, attempt to estimate the potential yield.

While recognizing the desirability of competing for advertising funds as a means of broadening the appeal of public broadcasting, on balance I would oppose its use at this stage. First, the extent of the additional funds generated, as against present underwriting of public broadcasting, is highly conjectural. Moreover, such a policy would divide the educational broadcasting community, most of whom strongly oppose commercialization. In addition, strong opposition from the commercial broadcasters would prevent its early adoption. A potent argument for reserving channels for exclusive use of educational broadcasting is the need to construct a broadcast service with different economic dynamics.

\section{F. Pay-TV}

Professor Netzer is properly skeptical of pay-TV as a significant aid to public broadcasting. ${ }^{31}$ A per-program pay service would tend to be an upper-income-

\footnotetext{
${ }^{20}$ Id.

${ }^{80} \mathrm{Id}$. at 4 .

${ }^{81}$ Id. at $2-3$.
} 
minority experience, whereas public broadcasting ideally should be a mass experience conferring benefits on the whole society. As a practical matter, also, subscription TV requires a tremendous outlay of resources to acquire programs, equip subscribers, and stimulate interest, and public broadcasting would be grossly underfinanced for such an undertaking. Nevertheless, Netzer believes that subscription television should play some role in the financing of public broadcasting, if only in the use of a charge for occasional special programs of a very costly nature.

It is highly unlikely that educational broadcasting can undertake to establish its own subscription service. At most it might work out an arrangement with stations regularly engaged in subscription service at some future date. Any assessment of the potential of subscription television to serve public broadcasting must await the establishment and development of regular subscription service, as well as the development by public broadcasting of programs that would attract paying customers.

\section{IV}

\section{Concluding Observations}

Although the first ETV station began in Houston in 1953, not until very recently has a substantial structure of stations and program suppliers emerged. Only five years ago, at a time when Japan invested over \$200 million annually in her educational broadcasting service, the total yearly income of all U.S. ETV stations was only $\$ 35$ million.

In the past five years, with increased financial support for public broadcasting, there has been a marked acceleration in the progress toward professionalism. Now, public broadcasting urgently needs a ten-year economic charter, permitting a substantial build-up in its program and transmission capacity. The charter should include establishment of an earmarked fund and a special tax. Such a commitment would insure the Corporation for Public Broadcasting relative freedom from the pressures and vagaries of annual appropriation procedures. This freedom is essential to the Corporation in pursuing its appointed tasks of guiding, stimulating, and supporting educational broadcasters.

The tax should yield at least \$roo million annually, and it should be supplemented by $\$ 30$ million in annual facilities grants appropriated by Congress and administered through the Department of Health, Education, and Welfare. These sums would overlay at least $\$ 50$ million derived from public, business, local and state governments, and other sources. For public television's needs, a total annual budget of $\$ 180$ million is barely minimal; it is defensible only if there is assurance that these monies would be forthcoming for each of the next ten years. On that basis, public broadcasting would have a reasonable chance of demonstrating the major contributions it can make in improving the quality of American life and the wis- 
dom of subsequently increasing the level of investment in public broadcasting to $\$ 270$ million or more as required.

It is critical that the commitment to finance public broadcasting's further development be made immediately if we are to preserve the gains of the past few years. Thus the choice of the tax to provide the funds becomes a political decision. None of the alternatives is easy, and none can be adopted without the determined and united efforts of the Nixon Administration and of the Democratic leadership of the Senate and House of Representatives. The best choice lies between a tax on sets and a tax on broadcast revenues. Either is economically feasible. Either will yield the annual sums necessary for the support of a developing public broadcasting service during the next decade. Either has ample justification in theory and practice, and either is in the public interest.

It is conceivable that Congress, having voted to reduce the oil depletion tax benefit, could be persuaded to consider on its merits a tax on broadcasting. All that is required is the approval of President Nixon and of Congressman Wilbur Mills. ${ }^{32}$ And this, in turn, requires a highly articulate, organized, and persistent public voice.

\footnotetext{
${ }^{32}$ Unfortunately, neither is committed to a plan for the long-term financing of public broadcasting. One proposal under consideration in the Administration is to seek a three-year authorization from Congress under which the government would match annually the sums raised for the programming and operating expenses of stations provided by local and state governments, foundations, business, and public donors. This is designed as an interim measure until the Administration decides the time is ripe to propose a special tax or other device to support ETV.
} 